\title{
Effect of different nitrogen levels through Neem coated urea and calcium sprays on leaf and soil NPK and Ca status and phytotoxicity in peach
}

\author{
Kamal K. Pande*, D.C. Dimri ${ }^{1}$ and Sanjay Kumar ${ }^{2}$ \\ Krishi Vigyan Kendra (ICAR-VPKAS), Kafligair, Bageshwar (Uttarakhand) India \\ (Email : pande4kamal@gmail.com)
}

\begin{abstract}
A two year investigation was conducted at Krishi Vigyan Kendra (ICAR- VPKAS), Kafligair- Bageshwar during 2016 and 2017 in peach cv. RED JUNE with ten treatments viz., $375 \mathrm{~g} \mathrm{~N}$ per tree $+0.5 \% \mathrm{CaCl}_{2}\left(\mathrm{~T}_{1}\right), 375 \mathrm{~g} \mathrm{~N}$ tree-1 $+1.0 \% \mathrm{CaCl}_{2}\left(\mathrm{~T}_{2}\right), 375$ $\mathrm{g} \mathrm{N}$ tree $^{-1}+1.5 \% \mathrm{CaCl}_{2}\left(\mathrm{~T}_{3}\right), 500 \mathrm{~g} \mathrm{~N}_{\text {tree }}^{-1}+0.5 \% \mathrm{CaCl}_{2}\left(\mathrm{~T}_{4}\right), 500 \mathrm{~g} \mathrm{~N}$ tree $^{-1}+1.0 \% \mathrm{CaCl}_{2}\left(\mathrm{~T}_{5}\right), 500 \mathrm{~g} \mathrm{~N}^{-1} \mathrm{tre}^{-1}+1.5 \% \mathrm{CaCl}_{2}\left(\mathrm{~T}_{6}\right), 625$ $\mathrm{g} \mathrm{N}$ tree ${ }^{-1}+0.5 \% \mathrm{CaCl}_{2}\left(\mathrm{~T}_{7}\right), 625 \mathrm{~g} \mathrm{~N}$ tree $^{-1}+1.0 \% \mathrm{CaCl}_{2}\left(\mathrm{~T}_{8}\right), 625 \mathrm{~g} \mathrm{~N}$ tree ${ }^{-1}+1.5 \% \mathrm{CaCl}_{2}\left(\mathrm{~T}_{9}\right), 500 \mathrm{~g} \mathrm{~N}$ tree ${ }^{-1}+$ Water spray $\left(\mathrm{T}_{10}\right.$ control). The source of nitrogen fertilization was neem coated urea. The experimental findings revealed that maximum leaf nitrogen content was estimated under $\mathrm{T}_{9}(3.721 \%$ and $3.838 \%$ in 2016 and 2017, respectively), while maximum leaf phosphorus content was estimated under $\mathrm{T}_{1}(0.450 \%)$ in first and $\mathrm{T}_{3}(0.456 \%)$ in second year. During both the years, the maximum leaf potassium content was estimated under $\mathrm{T}_{2}$ (2.096\% and $2.110 \%$ in 2016 and 2017, respectively). The highest leaf calcium content was estimated under $\mathrm{T}_{3}$ (1.735\% in 2016 and $1.744 \%$ in 2017). Irrespective of nitrogen fertilization levels, highest calcium chloride concentration (1.5\%) resulted in phytotoxicity which was evident by marginal leaf scorching. Significant differences for available soil nitrogen were found, while other studied nutrients did not differ significantly.
\end{abstract}

Key Words : Nitrogen levels, Neem coated urea, Calcium chloride, Leaf, Soil nutrient status

View Point Article : Pande, Kamal K., Dimri, D.C. and Kumar, Sanjay (2018). Effect of different nitrogen levels through Neem coated urea and calcium sprays on leaf and soil NPK and Ca status and phytotoxicity in peach. Internat. J. agric. Sci., 14 (2) : 381-388, DOI:10.15740/ HAS/IJAS/14.2/381-388. Copyright@ 2018: Hind Agri-Horticultural Society.

Article History : Received : 11.04.2018; Revised : 03.05.2018; Accepted : 18.05.2018

\footnotetext{
* Author for correspondence:

${ }^{1}$ Department of Horticulture, G.B. Pant University of Agriculture and Technology, Pantnagar, U.S. Nagar (Uttarakhand) India

${ }^{2}$ ICAR- VPKAS, Almora (Uttarakhand) India
} 